\title{
ע Virtuaalinen vuorovaikutus ruumiillisuuden näkökulmasta - Sosiaalinen kohtaaminen ja yhteistoiminta virtuaalisessa tavoitteellisessa toiminnassa ja jumalanpalveluksessa
}

\section{Tiivistelmä}

Koronapandemian aikana yhdessä työskentely ja opiskelu virtuaalisten alustojen avulla on lisääntynyt, kun kokoontuminen on ollut riski ja rajoitukset ovat kokoontumiset kieltäneet. Myös jumalanpalvelukset on välitetty virtuaalisesti seurattaviksi ja osallistuttaviksi. Artikkeli vastaa kysymyksiin, millaista virtuaalisessa ympäristössä toimiminen on luonteeltaan sekä miten virtuaalinen etätyöskentely soveltuu erilaisiin tavoitteellisille yhdessä toimimista edellyttäville sosiaalisille tilanteille ja uskonnolliselle toiminnalle. Tarkastelua ohjaa ruumiinfenomenologiassa huomioitu seikka, että ihminen on ruumiillinen olento. Artikkeli siis kysyy, millaista virtuaalinen toiminta on ruumiillisuuden valossa. Myös virtuaalinen yhteistyö on luonteeltaan ruumiillista toimintaa: vuorovaikutus tapahtuu myös virtuaalisesti kehollisten toimintojen ja aistien avulla. Kehollinen viestintä on kuitenkin virtuaalisissa palveluissa rajoittunutta. Parhaiten ne soveltuvat sellaiseen tavoitteelliseen yhteistoimintaan, joka rakentuu pitkille ja harkituille puheenvuoroille. Pitkän ajan pelkästään virtuaalisten palveluiden varassa toimimisella on huonoja seurauksia niin opinnoissa kuin työpaikoilla, joissa sosiaalisella toiminnalla ja niiden kautta rakentuvilla tunnesiteillä on olennainen merkitys. Jumalanpalvelukseen osallistuminen on nimenomaisesti ruumiillista toimintaa, jossa korostuu kirkossa olemisen, muiden läsnäolon ja vuorovaikutuksen merkitys. Uskonnollisuus ylipäätään on luonteeltaan ruumiillista siinä mielessä, että se on elettyä eikä intellektuaalista 
opin ja opetuksen omaksumista ja ymmärtämistä. Jumalanpalveluksen virtuaalisuus väistämättä hukkaa paljon tilaisuuden ruumiillisesta ulottuvuudesta, mutta ei kuitenkaan kaikkea. Jumalanpalveluksen tarkoituksesta ja merkityksestä toteutuu paljon myös virtuaalisesti välitettyyn tilaisuuteen osallistumisen kautta.

Avainsanat: virtuaalinen yhteistoiminta, virtuaalinen vuorovaikutus, virtuaalisuus, ruumiillisuus, uskonnollisuus, virtuaalinen jumalanpalvelus, tavoitteellinen yhteistoiminta, yhteistoiminnan filosofia

\section{Johdanto}

Ihmisten arki on vuonna 2018 alkaneen koronapandemian seurauksena mullistunut monin tavoin. Koronapandemian yhtenä vaikutuksena on ollut, että ihmiset ovat pysyneet kotona. Ne, jotka ovat suinkin voineet tai ne, jotka on siihen pakotettu, ovat tehneet työnsä ja opintonsa kotoa etäyhteyksien avulla. Myös suurin osa uskonnollisista rituaaleista on järjestetty virtuaalisesti osallistuttaviksi. Etäyhteyksien varassa toimiminen ja siitä aiheutuvat inhimilliset seuraukset ovat akuutti kysymys, jota on tarkasteltava monesta eri näkökulmasta. Virtuaalisesti järjestetyn tavoitteellisen yhteistoiminnan tarkasteleminen on tärkeää kaikkien seurakuntien hengellistä työtä tekevien kannalta, koska myös seurakuntien työyhteisöjen sisäiseen työhön on otettu virtuaaliset välineet käyttöön. Virtuaalisesti järjestetyn jumalanpalveluksen tutkiminen on tärkeää seurakuntien hengellisen työn kannalta.

Tässä artikkelissa pyrin vastaamaan kysymyksiin, millaista vuorovaikutus ja yhdessä toimiminen ovat luonteeltaan virtuaalisessa ympäristössä sekä miten virtuaalinen etätyöskentely soveltuu erilaisille tavoitteellisille yhdessä toimimista edellyttäville sosiaalisille tilanteille sekä uskonnolliselle toiminnalle. Artikkelin tehtävänä on näihin kysymyksiin vastaamalla tutkia tavoitteellista toimintaa ja uskonnollista toimintaa virtuaalisena sosiaalisena kohtaamisena ja näin peilata lähtökohtaisesti erilaisia (virtuaalisia) toiminnan muotoja toisiinsa. Keskityn uskonnollisen toiminnan osalta Suomen evankelis-luterilaisen kirkon jumalanpalvelukseen. Näiden lähtökohtaisesti erilaisten sosiaalisen toiminnan muotojen peilaaminen antaa edellytykset tutkia, onko sosiaalisessa kohtaamisessa joitakin toiminnan muodosta riippumattomia yhteisiä piirteitä. Virtuaalisen tavoitteellisen yhteistoiminnan ja jumalanpalveluksen peilaaminen paljastaa niiden sosiaalisen yhteistoiminnan luonteesta kiinnostavia seikkoja. 
Artikkelin aihe on ajankohtainen, ja lisäksi on luultavaa, että virtuaalisesta vuorovaikutuksesta vakiintuu monenlaisessa tietotyössä ja opiskelussa tavallinen tapa toimia yhdessä myös pandemian jälkeen (etätyön lisääntymisen vaikutuksista koulutukseen ks. esim. Wiklund ym., 2021; Lehikoinen, 2021, ja työntekoon ja työelämään ks. esim. Lindström, 2021). Virtuaalinen työskentely on monin tavoin kustannustehokasta niin työnantajan ja koulutuksen tai tapahtuman järjestäjän kuin työntekijän, opiskelijan ja osallistujan kannalta. Virtuaalisuus säästää merkittävästi aikaa ja vaivaa, mikä fyysisesti yhteen kokoontumisessa kuluu matkustamiseen. Lisäksi säästyy tiloihin kuluvia kustannuksia, kun virtuaalisen työskentelyn vakiintumista voidaan käyttää tilojen vähentämisen perusteena. Toisaalta joitakin työnantajalle kuuluvia kustannuksia siirtyy helposti työntekijän vastuulle. Joka tapauksessa virtuaalisten etäyhteyksien mahdollisuudet omaksuttaneen aiempaa vahvemmin myös uskonnollisten yhteisöjen käytänteisiin (Salminen, 2021).

Tarkoitan virtuaalisella ympäristöllä koronapandemian myötä yleisesti käytössä olevia videokeskustelualustoja (esimerkiksi Teams ja Zoom), joilla voi välittää omalta laitteelta ääntä ja kuvaa toisille samassa virtuaalisessa tilassa oleville. Käytännössä tällaiset alustat mahdollistavat tapaamisen ja kohtaamisen virtuaalisesti oman internetiin yhdistetyn laitteen, kuten tietokoneen tai puhelimen, avulla. Lisäksi alustat antavat mahdollisuuden kirjalliseen viestintään tapaamisen kirjoitustilan eli chatin avulla. Sosiaalisella tilanteella tarkoitan yksinkertaisesti kahden tai useamman ihmisen vuorovaikutustilannetta. Yhdessä työskentelemisen ja kohtaamisen mahdollistavat virtuaaliset palvelut eroavat jonkin verran toisistaan ja niillä on erilaisia ominaisuuksia esimerkiksi sen suhteen, kenen kuva on milloinkin näkyvissä. Tässä artikkelissa tarkastelen virtuaalisesti tapahtuvaa sosiaalista yhteistoimintaa, jossa osallistujat ovat reaaliaikaisessa sosiaalisessa vuorovaikutuksessa ääntä ja kuvaa välittävän virtuaalisen palvelun avulla. Käsittelen virtuaalista työskentelyä yleisellä tasolla enkä tee vertailuja eri virtuaalisten alustojen välillä.

Tarkoitan tavoitteellisella yhteistoiminnalla sellaista yhdessä toimimista, jossa tarkoituksena on jonkin tietyn, melko tarkasti määritellyn tavoitteen saavuttaminen, mistä toimintaan osallistuvat ovat tietoisia. Tällaista toimintaa on esimerkiksi työpaikan kokous ja luento yliopistolla. Tavoitteellisen sosiaalisen toiminnan osalta keskityn sellaiseen työhön, jota on lähtökohtaisesti mahdollista tehdä virtuaalisesti. Aiheena on siten niin sanottu tietotyö, joka ei edellytä fyysistä käsin tekemistä. 
Lähestyn edellä mainittuja kysymyksiä ja artikkelin tehtävää ruumiillisuuden merkityksen huomioivan, ruumiinfenomenologiaan perustuvan tutkimuksen avulla. Kun tarkastelen yhteistoimintaa, hyödynnän lisäksi yhteistoiminnan etiikkaa koskevaa moraalifilosofista tutkimusta. Esittelen teoreettiset lähtökohtani lähemmin seuraavassa alaluvussa ja lisäksi esittelen ruumiillisuutta koskevat keskeiset ideat kolmannessa alaluvussa.

Vuorovaikutusta ja yhteistoimintaa virtuaalisessa tilassa on tutkittu monilla eri tieteenaloilla ja monista näkökulmista: esimerkiksi psykologian alalla (esim. Sundar, 2015), kasvatustieteissä (esim. Ellis \& Goodyear, 2010), johtamis- ja organisaatiotutkimuksessa (esim. Kuepers, 2010; Asatiani ym., 2021), tietojenkäsittelytieteessä ja tieteen- ja teknologiantutkimuksessa (esim. Ignat ym., 2018; Metzinger, 2018), viestintätieteessä (esim. Fay \& Kline, 2011) ja robotiikka koskevassa tutkimuksessa, jossa kysymyksenä on robotille luotava ruumis ja sen merkitys vuorovaikutuksessa ihmisen kanssa (esim. Hosseini ym., 2018). Virtuaalisen vuorovaikutuksen ja yhteistoiminnan luonnetta koskevaa tutkimusta on tehty vain vähän (Martikainen ym., 2019:302). Martikainen ym. (2019) sekä Wikström ym. (2020) ovat vertailleet yhdessä tehtävää visuaalis-spatiaalista ongelmanratkaisua fyysisesti läsnä ollen ja virtuaalisesti, mikä on olennainen avaus virtuaalisen vuorovaikutuksen luonteen tutkimukseen, mutta kertoo lopulta todellisen elämän virtuaalisesta yhteistoiminnasta vain vähän. Ruumiillisuuden lähtökohta tarjoaa mielekkään ja hedelmällisen näkökulman virtuaalisen vuorovaikutuksen ja yhteistoiminnan filosofiseen tutkimukseen. Teoreettisesti artikkeli on analyyttista, fenomenologista ruumiillisuutta hyödyntävää filosofista tutkimusta.

\section{Teoreettiset lähtökohdat}

Ruumiinfenomenologia perustuu ranskalaisen Maurice Merleau-Pontyn (1908-1961), erityisesti tämän pääteoksessaan Phénomenologie de la perception (1945) esittämään filosofiaan. (Viittaan teoksen englanninkieliseen käännökseen, Merleau-Ponty, 2012.) Merleau-Ponty hyödynsi fenomenologisen filosofisen virtauksen alkuunpanijan Edmund Husserlin (1859-1938) teorioita ruumiillisesta subjektista ja niin sanotusta eletystä ruumista. Tämä artikkeli asettuu osaksi ruumiillisuutta käsittelevää ja siihen nojautuvaa, jatkuvasti merkittävämmäksi muodostuvaa filosofisen tutkimuksen virtausta (ks. esim. Va- 
rela, Thompson \& Rosch, 1991; Cataldi, 1993; Schott, Heinämaa \& SongeMoller, 2010; Vasquez, 2011).

En kuitenkaan osallistu tällä artikkelilla ruumiinfenomenologiseen filosofiseen keskusteluun, vaan ainoastaan nojaudun siihen perustuvaan tutkimukseen, kun tutkin etäyhteyksien varassa toimimista. En myöskään hyödynnä suoraan Merleau-Pontyn tai Husserlin filosofioita, vaan niiden perustalta kehiteltyjä teorioita, joissa keskeisiä käsitteitä ruumiillisuuden lisäksi ovat subjektia sekä tämän tietoa ja kognitiota koskevat käsitteet intersubjektiivisuus, enaktiivisuus ja interkorporeaalisuus. Esittelen nämä käsitteet jäljempänä lähemmin. Tarkoituksenani ei ole pyrkiä sanomaan ruumiillisuudesta tai ruumiinfenomenologiasta kaikkea olennaista. Sen sijaan otan lähtökohdakseni ruumiillisuuden näkökulman ja keskityn ruumiinfenomenologian osalta seikkoihin, jotka ovat nähdäkseni kaikkein olennaisimpia virtuaalisen yhteistoiminnan kannalta. Ruumiinfenomenologian lähtökohtiin nojautumisen lisäksi hyödynnän viestintää ja erityisesti kehollista vuorovaikutusta koskevaa tutkimustietoa (erit. McNeill, 2015; Knapp ym., 2013).

Tutkin yhteistoimintaa Jaana Hallamaan (2017) yhteistoiminnan etiikan avulla. Teorian perustana on pitää ihmistä toimijana, joka otetaan lähtökohdaksi myös sosiaalista yhteistoimintaa tutkittaessa. Teoria noudattaa metodologisen individualismin paradigmaa, jossa inhimillistä todellisuutta, sosiaalista toimintaa ja sosiaalisia rakenteita tutkitaan yksilön näkökulmasta. Hallamaa määrittelee toimijuuden kolmeksi kriteeriksi intentionaalisuuden, rationaalisuuden ja kyvykkyyden. Intentionaalisuusehto tarkoittaa, että toimija on jatkuvasti jotakin tavoitteleva olento; tästä näkökulmasta myös passiivisuus on toimintaa ja toteuttaa jotakin toimijan tavoiteltavana ja hyvänä pitämää päämäärää. Rationaalisuusehto tarkoittaa, että toimijalla on toimintaan ryhtyessään jollakin perusteella järkevinä pitämiään keinoja tavoitella päämääräänsä, jota tämä niin ikään pitää jollain perusteella järkevänä. Tämä ehto ei kuitenkaan tarkoita, että toimijan järkevinä pitämät perustelut olisivat objektiivisesti järkeviä, vaan ehto viittaa ainoastaan toimijan omiin käsityksiin. Kyvykkyysehto tarkoittaa, että toimijan on oltava edes jollain tavalla kyvykäs tavoittelemaan päämääräänsä valitsemillaan keinoilla (Hallamaa, 2017:20-24). Näiden käsitteellisten ehtojen perustalta yhteistoiminta näyttäytyy eri toimijoiden hyvänä pitämien tavoitteiden ja keinojen yhteen sovittamisena, ristiriitoina ja yhteen kietoutumisena. Aiheen kannalta on olennaista, millä tavoin toimijat sitoutuvat yhteistoiminnassa yhteisen ja jaetun tavoitteen toteuttamiseen. 


\section{Ruumiillisuus}

Filosofinen tutkimus on luonteeltaan intellektuaalista rationaaliseen ja loogiseen päättelyyn perustuvaa ajattelua. On mielekästä esittää, että käytännön elämässäkin on pyrittävä toimimaan tavoilla, jotka nojautuvat yleisesti hyväksyttäviin rationaalisiin perusteluihin. Tässä merkityksessä rationaalisuus tarkoittaa tarkalleen ottaen eri asiaa kuin Hallamaan yhteistoiminnan etiikan rationaalisuusehto. Tässä tarkoittamani rationaalisuus viittaa yleisesti hyväksyttäviin järkisyihin, Hallamaan rationaalisuusehto viittaa perusmerkityksessään vain yksilön itse omalle toiminnalleen kohdistamiin perusteluihin. Joka tapauksessa on perusteltua pitää yleiseen hyväksyttävyyteen pyrkivää rationaalisuutta ihanteena, johon arkisessa elämässä ja yhteiskunnan kaikilla aloilla ja toiminnoissa on pyrittävä. Laajasti ottaen moderni länsimainen filosofinen ihmiskäsitys ja filosofinen tarkastelu on perustunut niin sanotun rationaalisuusteesin varaan. Tämän käsityksen mukaan ihmisen toimintaa ohjaa pyrkimys toimia objektiivisesti ja yleisesti hyväksyttävien rationaalisten perusteiden varassa. Tällaiseen rationaalisuuteen viitataan termillä instrumentaalinen rationaalisuus (Kolodny \& Brunero, 2020). Charles Taylor (2007) on esittänyt, että instrumentaalinen rationaalisuus on valistuksesta lähtien muotoutunut ihmiskäsityksen yhdeksi perustaksi.

Rationaalisuusteesistä ei ole syytä luopua siinä mielessä, että koherenttiuteen, loogisuuteen ja järkevyyteen ei tarvitsisi pyrkiä yhteiskunnan eri aloilla ja arkisessa elämässä. Ruumiillisuuden merkityksen huomioiva filosofia kuitenkin esittää, että ihmisenä olemisen ehtoja ei voi redusoida rationaalisuuteen pyrkimykseksi. Ihmisenä oleminen ei ole intellektuaalinen projekti. Sen sijaan ihmisenä olemista on tarkasteltava siitä lähtökohdasta, tai ainakin ottamalla huomioon se, että ihminen on ruumiinsa. Me olemme, toimimme ja ilmenemme toisillemme sekä vuorovaikutamme toistemme kanssa ruumiimme kautta. Tähän arkipäiväiseen huomioon nojautuvan tutkimuksen merkityksen kasvun taustana on ruumiillisuuden sivuuttaminen tai ainakin väheksyminen pitkälti koko länsimaisen filosofian historiassa. Nykyajan mielen ja ruumiin suhdetta koskevan filosofian välittömänä taustana on valistuksen projekti, jonka eri kysymyksenasetteluita yhdisti ihmisyyden ja ihmisen toiminnan tarkasteleminen mielenfilosofian kautta ja rationaalisen ajattelun valossa. (Bristow, 2017.) Valistuksen mielenfilosofian lähtökohdan teoreettisena muotoiluna oli René Descartesin mielen ja ruumiin erotteleva dualismi, jossa oleminen kiteytettiin mielensisäiseksi ajattelun kysymykseksi (Pihlström, 
2020). Samalla emotionaalisuus on jäänyt rationaalisuuden varjoon. Tunteiden merkityksen vähättelyllä on tietysti pitkä historia länsimaisessa filosofiassa, mistä keskeisimpänä esimerkkinä on antiikin stoalainen ajattelu, jonka mukaan tunteet ovat seurausta harkintakyvyn pettämisestä (Scarantino \& de Sousa, 2018: luku 10).

Ruumiillisuutta on mielekästä pitää perustavana, ensimmäisen kertaluokan ihmisyyttä koskevana seikkana, josta filosofisessa tarkastelussa voidaan lähteä liikkeelle (Merleau-Ponty, 2012:147-148). Subjektin ruumiillinen sijoittuminen maailmaan on Husserlin filosofiaan perustuvan fenomenologian yhtenä lähtökohtana. Yhtenä osana ruumiillista maailmaan sijoittumista on se, että jo maailmasta saatavan tiedon prosessi on luonteeltaan ruumiillinen, koska tietoa välittömästä lähiympäristöstä saadaan aistien avulla (Tewes, Durt \& Fuchs, 2017:2-4). Aistimisen ruumiillisuudella on olennainen ihmisenä olemista koskeva ulottuvuus. Nimittäin aistimisen ruumiillisuus merkitsee, että ihminen on väistämättä johonkin fyysiseen kontekstiin sidottu. Voimme saada aistein tietoa vain siitä ja sen kautta, mitä on välittömässä fyysisessä ympäristössämme. Tästä näkökulmasta voidaan ottaa huomioon se, että ihmisenä oleminen on sosiaalisesti ja kulttuurisesti sidonnaista. Jo perustavat käsityksemme maailmasta muotoutuvat tietyn historiallisen ja kulttuurisen ajattelutavan puitteissa ja sosiaalisten suhteiden kautta (esim. Durt, 2017:6668). Näin ruumiillisuuden lähtökohdakseen ottavan filosofian ihmiskäsityksen voi perustella olevan luonteeltaan intersubjektiivinen: ihmisenä olemisen lähtökohtana ei ole atomistinen minuus, vaan se, että ihminen on sosiaalisten suhteiden kautta persoonaksi kehittyvä ja persoonana oleva olento (Taipale, 2010).

Ruumiinfenomenologista teoriaa on viime aikoina kehitelty vuorovaikutuksessa empiirisen psykiatrisen, psykologisen ja kognitiivis-neurotieteellisen tutkimuksen kanssa (ks. Thomas Fuchsin johtama yhteistyöhanke TESIS), mutta tutkimuksessa käytetyt filosofiset käsitteet kuitenkin tulevat Husserlin ja Merleau-Pontyn filosofioista. Ruumiinfenomenologiassa subjektin tietoisuus ja kognitio selitetään enaktiivisuuden käsitteen avulla. Enaktiivisuudella tarkoitetaan sitä, että kognitio muodostuu subjektin toiminnassa ja vuorovaikutuksessa suhteessa maailmaan ja toisiin ihmisiin. Enaktiivisuus sisältää siten sen, että yksilön kognitio ja näin subjektin olemassaolon perusta on väistämättä intersubjektiivisissa eli yksilöiden välisissä suhteissa muotoutuvaa. Yksilöiden välisyyttä taas selitetään ruumiillisuuden valossa interkorporeaa- 
lisuuden käsitteen avulla, jolla viitataan yksinkertaisesti ruumiillisten yksilöiden välisyyteen.

Todellisuuden objektiivinen luonne perustuu subjektien intersubjektiivisesti ja interkorporeaalisesti jaettuun kokemukseen todellisuudesta. Subjektin perustana olevat interkorporeaalisuus ja intersubjektiivisuus tarkoittavat myös, että subjektin koko käsitys maailmasta ei ole subjektista riippumatonta ja objektiivista, vaan subjektin arvojen kyllästämässä elämistodellisuudessa tulkittua. Arvojen kyllästämä elämistodellisuus on subjektin oma, mutta se muodostuu väistämättä intersubjektiivisissa suhteissa. Elämistodellisuuden käsitteen avulla voidaan selittää, millä perusteella ihminen suuntaa toimintansa, mitä ihminen pitää arvokkaana ja tavoiteltavana ja millaisia moraalisia arvostelmia hän tekee (Pihlström, 2010:237-244). Tätä selitetään myös kulttuurin käsitteellä, jolla tarkoitetaan koko jaettua inhimillistä todellisuutta, johon kuuluu esimerkiksi jaettu kieli, jaettuja ideoita, arvoja ja arvostelmia, tapoja ja käytänteitä (Tewes, Durt \& Fuchs, 2017:6-10).

Intersubjektiivisuuden kautta muotoutuva maailmaa koskeva tieto syntyy subjektien välisessä kommunikaatiossa, joka on luonteeltaan myös ruumiillista ja interkorporeaalista. Tietoa ei välitetä ainoastaan sanoin, vaan myös elein ja ilmein. Myöhemmät kehollista viestintää koskevat kommunikaatioteoriat ovat huomioineet saman: sosiaalisessa vuorovaikutuksessa tapahtuva viestintä on pitkälti kehollista ja kehollisten ilmaisujen jatkuvaa, tiedostettua ja tiedostamatonta tulkintaa. Tyypillisesti sosiaalinen vuorovaikutus perustuu viestinnällisesti vain pienessä määrin sanalliseen asiasisällölliseen ilmaisuun ja sen tulkintaan. Merkittävämmässä roolissa ovat keholliset viestit, kuten asennot, ilmeet, eleet ja äänenpainot. (McNeill, 2005:3-5; Knapp ym., 2014:3-10.) Interkorporeaalisuudesta avautuu näkökulmia affektien ja emootioiden jaettuun luonteeseen ja ruumiillisuuteen. Tunteet ovat sosiaalisissa suhteissa syntyviä ja niitä ohjaavia kokemuksia, jotka ovat luonteeltaan ruumiillisia; tätä selittää käsite interaffektionaalisuus. (Tewes, Durt \& Fuchs, 2017:1-8.)

Kaikki sosiaalinen vuorovaikutus ei myöskään tapahdu fyysisen etäisyyden päässä kehollisten viestien ja puheen varassa. Kosketus on keskeinen osa tapojamme olla yhdessä ja kosketus viestii paljon. Kosketus on kulttuurisesti tarkasti säädeltyä ja normitettua. Sopimatonta koskettamista pidetään moraalisesti moitittavana, toisen ihmisen yksityisyyteen väärällä tavalla kajoavana. Jo liian lähelle värällä tavalla tulemista pidetään tungettelevana ja ihmisen omaa fyysistä tilaa loukkaavana. Kulttuurisesti ja sosiaalisesti hyväk- 
sytyllä koskettamisella on kuitenkin lähtökohtaisesti positiivisia merkityksiä. Esimerkiksi kätteleminen on keskeinen osa länsimaalaisia sosiaalisia tapoja. Viestinnällisesti koskettaminen välittää erityisesti emotionaalisia sisältöjä. Koskettaminen luo yhteyksiä ihmisten välillä ja sitoo heitä yhteen (Gallace \& Spence, 2016). On tärkeä kysymys, millä tavoin koskettamiseen liittyvät sosiaaliset normit muuttuvat pandemian vaikutuksesta ja mitä kaikkia seurauksia sillä on. Tässä artikkelissa ei ole kuitenkaan mahdollista tarkastella koskettamisen merkityksiä vuorovaikutuksessa.

Ruumiillisuuden asettaminen lähtökohdaksi filosofiselle tarkastelulle antaa edellytykset huomioida emotionaalisuus ihmisenä olemisen ja toimimisen perusteiden tarkastelussa. Länsimainen rationaalisuuden ihanne on ruumiillisuuden merkityksen sivuuttamisen lisäksi johtanut emotionaalisuuden väheksymiseen ja ohittamiseen. Tietämisen ruumilllisuuden huomioiminen purkaa tunteiden ja rationaalisuuden dikotomista vastakkainasettelua. Kun tietäminen ymmärretään ruumiillisen sijoittumisen ja aistihavaintojen kautta tapahtuvaksi prosessiksi, tunteet voidaan selittää keskeisenä osana tätä prosessia. Aistihavaintojen kautta saatavan informaation jäsentämistä tiedoksi ei ole mielekästä ymmärtää ainoastaan intellektuaalisena prosessina. Olennaista on myös se, miten ihminen asiat kokee ja millaisia emotionaaliseen kokemukseen perustuvia arvostelmia tämä tekee.

\section{Virtuaalinen toiminta ruumiillisuuden näkökulmasta}

Mitä virtuaalisesta etätyöskentelystä voi sanoa sen valossa, että ihminen on ruumiillinen olento? Ensimmäinen, ei ehkä aivan ilmeinen, mutta kuitenkin nähdäkseni oikea johtopäätös on, että myös virtuaalinen toiminta on ruumiillista. Tämä johtopäätös kumpuaa näkökulmastani tarkastella ihmistä ruumiillisena olentona, mutta näkökulman perustalta voitaisiin päätyä myös sellaisiin johtopäätöksiin, että virtuaalista toimintaa ei ole mielekästä tarkastella ruumiillisuuden valossa tai että ihmisen ruumiillisuuden merkitys vähenisi virtuaalisessa toiminnassa. Näin ei kuitenkaan nähdäkseni ole. Ihminen viestii myös virtuaalisessa todellisuudessa kehollisten viestien avulla puhuen, ilmeillen ja elehtien sekä vastaanottaa tietoa ruumiillisten aistiensa kautta. Internetiin kytketyn laitteen kautta yhteydessä toisiin oleminen ei vapauta ihmistä jonkinlaiseen ruumiista irralliseen virtuaaliseen tilaan. Ruumis ei myöskään ikään kuin tempaudu irti fyysisestä sijastaan, vaan virtuaaliseen tapaamiseen 
osallistuva on jossain paikassa laitteensa kanssa. Älypuhelimen kanssa toimiminen toki mahdollistaa liikkumisen samaan aikaan, mutta liikkuessaankin ihminen on aina jossakin paikassa.

Virtuaalinen ympäristö tarjoaa välittömän fyysisen ympäristön lisäksi toisen ympäristön, johon ruumis voi samanaikaisesti kiinnittyä. Tämä ei kuitenkaan vapauta ihmistä ruumiinsa sidonnaisuuksista kuten aisteista, joiden varassa ihminen ottaa tietoa vastaan. Tässä mielessä internetin virtuaalinen työskentely ei tuo mitään radikaalisti uutta elementtiä elämään. Jo puhelin on mahdollistanut samanaikaisen "toisaalla olemisen" tai ainakin yhteyden fyysisesti kaukana olevan ihmisen kanssa. Joka tapauksessa ihminen kykenee tarkkailemaan ja niin sanotusti pitämään silmällä useitakin asioita samanaikaisesti. Ihminen voi kuitenkin keskittyä vain yhteen kognitiivista prosessointia edellyttävään asiaan kerrallaan. Tästä huomiosta avautuu yksi näkökulma siihen, miksi virtuaalinen yhdessä toimiminen voi olla raskasta.

Virtuaaliseen työskentelyyn osallistuvalla on käytännössä kaksi välitöntä ympäristöä, joiden välillä hän joutuu valitsemaan, kumpaan keskittyy. Toinen on fyysinen ympäristö, jossa ihminen ruumiinensa sijaitsee ja toinen on virtuaalinen ympäristö, johon sijoittuu paitsi itse virtuaalinen tapaaminen, myös kaikki laitteen kautta tuleva informaatio, kuten sähköpostit, internetsivut ja sovellukset. Nähdäkseni on perusteltua argumentoida, että oleminen fyysisesti toisessa paikassa kuin siellä, missä sosiaalinen toiminta tapahtuu, jo sinänsä vaikeuttaa keskittymistä sosiaaliseen kohtaamiseen ja tapaamiseen. Lisäksi se, että kohtaaminen tapahtuu tietokoneen välityksellä, tuo tilanteeseen tapaamisesta irrallisia ärsykkeitä. Kokousalustan voi vaihtaa toiseen ohjelmaan ja alkaa tehdä jotain muuta kenenkään muun huomaamatta. Ruumiinfenomenologian valossa voi sanoa, että virtuaalisuus tuo subjektin maailmaan sijoittumiseen toisen empiirisesti havaittavan kerroksen. Kuitenkin enaktiivinen vuorovaikutus onnistuu vain yhden empiirisen ympäristön kanssa kerrallaan. Toki myös fyysiseen läsnäoloon ja kokoontumiseen perustuvassa sosiaalisessa kohtaamisessa on monenlaisia häiriötekijöitä, jotka vievät huomiota itse sosiaaliseen toimintaan ja työskentelyyn keskittymiseltä. Tässä mielessä hankaluus keskittyä virtuaalisessa työskentelyssä ei johdu mistään täysin uudesta ihmiselämän ilmiöstä.

Virtuaalinen ympäristö ei ole fyysinen ympäristö sanan varsinaisessa merkityksessä, mutta se kuitenkin tuo keskinäiseen vuorovaikutukseen ihmisiä, jotka ilmenevät toisilleen ruumiidensa kautta ja viestivät toisilleen ruumiilli- 
sin keinoin. Näin sosiaalinen virtuaalinen ympäristö on empiirisesti koettava ympäristö. On syytä kysyä, millä tavoin virtuaalinen toiminta eroaa konkreettisesti fyysiseen läsnäoloon perustuvasta sosiaalisesta kanssakäymisestä. Ensin on jäsennettävä, millaisesta sosiaalisesta tilanteesta on kyse.

Sellaiset sosiaaliset työskentelytilanteet, joilla on jokin erityinen tavoite, voidaan eritellä kahteen yleiseen luokkaan. Ensimmäinen on tapaamisen tai kokouksen kaltainen tilanne, jossa työskentely perustuu yhteiseen keskusteluun. Tapaamisella on tyypillisesti keskustelua johdattava henkilö. Tällaisia tilanteita ovat esimerkiksi tapaamiset ja kokoukset, joissa suunnitellaan toimintaa ja sovitaan yhteisistä asioista. Myös opetustilanne voi olla luonteeltaan tällaista työskentelyä. Toinen työskentelytilanteen luokka on yhden henkilön puheeseen ja esiintymiseen perustuva tilanne, jossa muilla osallistujilla on lähinnä seuraajien ja kommentoijien rooli. Luennot, koulutukset ja opetustilanteet ovat usein luonteeltaan tällaisia. Työskentelytilanteet voivat myös olla yhdistelmä näitä malleja koostuen sekä yhden ihmisen esitelmästä että yhteisestä keskustelusta. Yhteinen keskustelu ei kuitenkaan onnistu, jos tilanteeseen osallistuu kovin monta ihmistä. Keskityn virtuaaliseen työskentelytilanteeseen, jossa toiminta perustuu yhdessä keskustelemiselle, mikä on seurakuntien työntekijöitä ja heidän työtään läheisesti koskettava kysymys.

\section{Vuorovaikutus ja yhteistoiminnan luonne virtuaalisessa keskustelussa}

Mielekkäässä keskustelussa osapuolet huomioivat toiset ja heidän näkemyksensä, jolloin puhe rakentuu aiemmin sanotun varaan. Siksi keskustelussa puhuttua ei voi täysin valmistella etukäteen, vaan on reagoitava myös uusiin, ehkä yllättäviinkin asioihin. Tietyn tavoitteen saavuttamiseen sitoutuneen keskustelun pyrkimyksenä on ymmärtää muita osapuolia, oppia, päästä yhteiseen käsitykseen, tehdä kompromisseja, mukautua uusiin tilanteisiin ja päättää asioista (Bohm, 1996:6-15). Tämän kaltaisessa yhteyksien luomisessa on intellektuaalisen tason ja rationaalisten argumenttien lisäksi merkitystä myös emotionaalisilla siteillä. Sara Heinämaa (1996:87) on kuvannut Merleau-Pontyn kommunikaatiota koskevaa filosofiaa siten, että tämä esittää ihmisten välisten yhteyden syntyvän "kasvojen" eikä "aivojen" kautta. Toisin sanoen vuorovaikutus on perustaltaan ruumiillista eikä intellektuaalista. 
Kehollisen viestinnän merkitys korostuu sosiaalisessa tilanteessa, joka perustuu osapuolten tasapuoliseen osallistumiseen keskustelijoina. Kehollisten viestien merkitykseen ja tulkintaan kiinnittää harvoin tietoisesti huomiota. Tekniikan asettamista rajoitteista johtuen virtuaalisella alustalla monet kehollisen viestinnän ja keskustelun tavat jäävät pois; esimerkiksi vain yksi voi olla äänessä samaan aikaan, äänessä ja kuvassa on pieni viive, ja on mahdotonta nähdä, milloin joku toinen aikoo sanoa jotakin. Kasvokkain tapahtuvassa keskustelussa päällekkäin puhuminen on melko tyypillistä ja oman näkökantansa sekä halunsa puhua seuraavaksi voi ilmaista äännähdyksin ja elein. On tavallista todeta varsin lyhyesti olevansa samaa mieltä tai suhtautuvansa varauksellisesti johonkin asiaan. Nämä elementit eivät ole täysin mahdottomia virtuaalisessa ympäristössä, mutta joka tapauksessa ne ovat rajoittuneempia, mistä syystä keskustelu on luonteeltaan enemmän sarja monologeja kuin dialogista vuorovaikutusta.

Keskustelun luonteesta ja sille asetetusta tavoitteesta riippuu, sopiiko sille virtuaalisen alustan tukema monologien sarja keskustelun mallina. Tietysti myös lyhyempien puheenvuorojen pitäminen on mahdollista, mutta aina yhden puhujan vallatessa koko tilanteen huomion syntyy paine sanoa jotain sisällöllisesti uutta ja olennaista silloin, kun on äänessä. Lisäksi viive hankaloittaa hyvin lyhyiden reaktioiden ilmaisemista. Jotkin tapaamiset ja sosiaaliset tilanteet rakentuvat kuitenkin punnituille ja pitkille puheenvuoroille ja niissä muotoilluille koherenteille argumenteille. Tällaiset tilanteet eivät erityisesti kärsi virtuaalisen ympäristön rajoitteista ja niitä tukee käytäntö pyytää puheenvuoro tilannetta ohjaavalta puheenjohtajalta.

Vuorovaikutusta koskevien huomioiden lisäksi on kysyttävä, minkälaisia vaikutuksia tapaamisen virtuaalisuudella on yhteistoiminnan teorian kannalta. Jonkin tavoitteen saavuttamiseen pyrkivää keskustelua on arvioitava siitä yhteistoiminnan luonnetta koskevasta näkökulmasta, kuinka syvää yhteiseen tavoitteeseen sitoutumista toiminta edellyttää. Tavoitteellinen keskustelu voi olla sitoutumisen kannalta melko vaatimatonta. Keskustelu voi olla esimerkiksi muodollinen, tiettyjen ennalta hyvin valmisteltujen asioiden päättämiseen keskittyvä kokous. Väitän, että mitä enemmän yhteiseen tavoitteeseen sitoutuneemmasta keskustelusta on kyse, sitä enemmän virtuaalisuus muodostuu rajoittavaksi tekijäksi. Tämä johtuu siitä, että yhteiseen tavoitteeseen sitoutuminen edellyttää edellä mainittua ideoimista, joka on hankalampaa virtuaalisessa kohtaamisessa verrattuna välittömään fyysiseen 
läsnäoloon perustuvassa vuorovaikutuksessa. Lisäksi yhteiseen ja etenkin vaativaan tavoitteeseen sitoutuminen merkitsee myös emotionaalisten siteiden luomista sekä toisiin toimintaan osallistuvien kanssa että myös itse toimintaan. Virtuaalinen vuorovaikutus kuitenkin vaikeuttaa osallistujien välisten emotionaalisten siteiden syntymistä (Hassett ym., 2018:175-176). Tästä syystä virtuaalista keskustelua helpottaa se, että osapuolet tuntevat toisensa ennalta ja heidän välilleen on jo voinut syntyä keskinäinen luottamus, jonka muodostuminen on hankalaa emotionaalisten siteiden syntyä rajoittavalla virtuaalisella alustalla.

Virtuaalinen alusta mahdollistaa kirjallisen viestittelyn puheen ja kuvan välittämisen ohella. Kirjoitettu teksti on viestinnän muotona siinä mielessä poikkeuksellinen, että toisin kuin kehollinen ilmaisu ja puhe, se ei ole ruumiillista. Teksti toki tuotetaan ruumiillisesti käsien avulla kirjoittaen ja se luetaan näköaistilla, mutta kuitenkin teksti ikään kuin irtoaa tuottajansa välittömästä ruumiillisuudesta ja luo oman objektinsa, joka säilyy ja johon voi myös palata myöhemmin. Vaikka kirjoitetun tekstin syvällisempi filosofinen analyysi ei ole tässä tarpeen, on huomioitava, että mahdollisuus kirjalliseen viestittelyyn luo elementin, jota ei ole fyysisissä tapaamisissa. Tietysti myös tavallisissa sosiaalisissa tilanteissa voi viestitellä oman laitteensa avulla tai vaikka kirjelappuja kädestä käteen antamalla toisten osallistujien kanssa, mutta etenkin pienemmässä ryhmässä tämä voisi kiinnittää huomiota ja muodostua häiriötekijäksi.

On merkitsevää, että virtuaalinen alusta luo kaikille tapaamiseen osallistuville yhteisen kommenttikentän eikä omalla laitteella kirjallinen viestittely siten luo tapaamisen ohelle siitä irrallista toimintoa. Kommenttikenttä voikin korvata edellä mainittuja virtuaalisen tapaamisen rajoituksia. Lyhyiden viestien avulla voi ilmaista nopeasti oman reaktionsa. Toisaalta tämä edellyttää kommenttikentän jatkuvaa seuraamista, mikä voi muodostua häiriötekijäksi keskustelulle. Lisäksi osa virtuaalisista alustoista tarjoaa mahdollisuuden lähettää yksityinen viesti toiselle kokouksen osallistujalle. Pienessäkin tapaamisessa voi siten olla käynnissä useita yhteisen tapaamisen ohella tapahtuvia viestienvaihtoja.

Vähintään yhtä tärkeää kuin pohtia virtuaalisen alustan käyttökelpoisuutta yksittäisissä tilanteissa on huomioida, mitä yhdessä työskentelyn kannalta merkitsee se, että kaikki työskentely tapahtuu pitkällä aikavälillä pelkästään virtuaalisesti. Monet asiat ovat virtuaalisesti hankalampia kehollisen viestinnän rajoittuneisuuden takia. Kuitenkin pitkällä aikavälillä merkitsevämpää 
lienee sosiaalisten siteiden syntymättä jääminen tai hiipuminen sekä ylipäätään työhön tai opiskeluun kuuluvan sosiaalisen elämän puuttuminen. Vaikka työpaikoilla, joissa työtä tehdään ryhmissä, vietetään työajan ulkopuolista, yhteistä aikaa harvemmin kuin esimerkiksi opiskeluaikana on usein tapana, sosiaalisilla suhteilla ja niihin kuuluvalla emotionaalisella tasolla on merkitystä myös työskentelyn kannalta.

\section{Virtuaalinen jumalanpalvelus}

Pandemian ajan kokoontumisrajoitukset ovat koskeneet myös uskonnollista toimintaa. Monet kirkon seurakunnat ovat järjestäneet jumalanpalveluksensa virtuaalisesti eli käytännössä "striimattuina" seurattaviksi (Ks. Salomäki, 2020:7; Salminen, 2021:1), jolloin osallistuja on voinut ainoastaan seurata tilaisuutta. Näin ollen osallistuminen on ollut yhdensuuntaista. Toisaalta jumalanpalveluksessa on voitu tervehtimällä ja muilla tavoin ottaa huomioon myös virtuaalisesti seuraavat, jolloin heidät on tunnustettu osana jumalanpalvelukseen osallistuvien joukkoa. Siten myös virtuaalisesti seuraavasta voi muodostua siihen osallistuva, vaikka tämä ei pääsekään varsinaiseen vuorovaikutukseen tilaisuuden toimittajien ja muiden siihen osallistuvien kanssa eikä voi vaikuttaa tilaisuuden kulkuun.

Jumalanpalvelus on uskonnollinen rituaali, joka alkaa kirkkoon astuessa ja päättyy sieltä joko itse jumalanpalveluksen tai kirkkokahvien jälkeen pois lähtiessä. Myös matkan kotoa kirkkoon ja takaisin voi nähdä osana rituaalia. Joka tapauksessa tilaisuuteen kuuluu kirkkoon saapuminen, mahdollisesti ovella tilaisuuden toimittajan tervehtiminen, kirkkosaliin astuminen, virsikirjan käsiin ottaminen, käytävää pitkin eteneminen ja oman paikan ottaminen. Ristinmerkin tekeminen ei ole suomalaisessa luterilaisuudessa yleistä, mutta yleiskristillisenä tapana se kertoo kirkkotilan pyhyydestä sekä jo kirkkoon astumisen ja kirkossa olemisen uskonnollisesta merkityksestä. Ennen jumalanpalvelusta saatetaan myös tervehtiä tuttuja, vaikka kirkkotilan ja alkavan jumalanpalveluksen pyhyyden kunnioittamisesta johtuvan tunnelman takia sosiaalinen tilanne ohjaa hiljentymään. Tilaisuuden aikana katse saattaa harhailla avaran tilan seinillä rakenteiden muotoja, taideteoksia ja yksityiskohtia silmäillen. Tämä kaikki on mitä syvimmässä merkityksessä ruumiillista.

Ruumiillista ei ole ainoastaan fyysisesti pyhässä tilassa oleminen, vaan jumalanpalvelukseen osallistutaan ruumiillisesti vuorovaikutuksessa sen toi- 
mittajien ja muiden siihen osallistuvien kanssa: yhdytään synnin- ja uskontunnustukseen, lauletaan virsiä, rukoillaan ja kumarrutaan alttarille ottamaan ehtoollinen vastaan. Kristillisen uskon ydinkappaleisiin nivoutuva ruumiillisuus tulee jumalanpalveluksessa konkreettiseksi ehtoollisessa, jossa Kristus otetaan vastaan syömällä ja juomalla (Törmä, 2015:13-16).

Jumalanpalveluksen alkuperäinen rituaalinen luonne harvoin toteutuu siinä mielessä, että siihen osallistuvat muodostaisivat tiiviin yhteisön, jonka koossa pysymistä ja identiteettiä jumalanpalvelus määrittäisi (Émile Durkheimin käsityksestä rituaalista yhteisöä koossa pitävänä liimana, ks. Stephenson, 2018). Tiiviin ja juuri tietyn, myös arkiseen elämään ulottuvan yhteisön sijaan, seurakuntien jumalanpalveluksiin osallistuvat muodostavat tyypillisesti joko arkisesta elämästä melko irrallisen tai satunnaisen yhteisön. Jumalanpalvelukseen osallistuvan kannalta on silti tärkeää, että tilaisuudessa toteutuu ajatus koolle kokoontuvasta seurakunnasta - kristillisyys ei ole kirkon uskontulkinnan perusteella yksilön vaan ennemmin yhteisön asia -, vaikka jumalanpalvelusyhteisöllä ja sen ihmisillä ei olisikaan mitään sijaa yksilön arkisessa elämässä.

Intellektuaalisella uskonasioiden jäsentämisellä ja ymmärtämisellä on tietysti paikkansa jumalanpalveluksessa, mikä toteutuu erityisesti saarnassa. Luterilaisuuteen kiinteästi kuuluvan saarnan merkityksen korostamisen juuret ovat jo Lutherin teologiassa, jossa uskon esitetään syntyvän kuulemisen kautta. Ehkä tästä teologisesta painotuksesta, saarnan keskeisyydestä ja valistuksessa muotoilluista ihmisenä olemisen lähtökohdista johtuu, että suomalaisessa luterilaisuudessa usko ymmärretään usein ihmisen mielensisäisenä ja rationaalisesti arvioitavana asiana. Manuel Vasquez (2011) on kiinnittänyt huomiota siihen, että uskon muotoutuminen rationaaliseksi asiaksi on yleinen länsimainen kehityskulku. Nojaudun eletty uskonto -tutkimusnäkökulman mukaiseen käsitykseen uskonnollisuuden luonteesta sen sijaan, että tarkastelisin uskoa mielensisäisenä rationaalisena asenteena.

Eletyn uskonnon paradigman mukaan uskonnollisuus ei ole uskonnollisen yhteisön muotoilemien opinkappaleiden omaksumista ja niiden mukaisesti elämistä. Uskonnollisuutta ei siis pidä arvioida pyrkimyksenä ymmärtää kristillinen opetus mahdollisimman hyvin ja sovittaa se oman ajattelun ja maailmankatsomuksen perustaksi. Sen sijaan uskonnollisuus on luonteeltaan nimenomaan elettyä ja toteutuu kaikessa uskonnollisessa toiminnassa sekä uskonnollisuuden vaikuttamassa arkisessa elämässä (McGuire, 2008). Toi- 
seksi yksilön uskonnollisuus muotoutuu väistämättä tämän omien käsitysten mukaisesti. Tällaisen uskonnollisuutta koskevan ajattelutavan perustalta esimerkiksi synkretismiksi kutsuttu uskonnollisten tapojen ja näkemysten sekoittuminen ei ole ainakaan lähtökohtaisesti kielteistä (McGuire, 2008:6-13).

Eletty uskonto -ajattelutapa huomioi sen, että ruumiillinen ulottuvuus on keskeinen osa paitsi jumalanpalvelusta myös uskonnollista elämää ylipäätään (Vasquez, 2011, ks. esim.:11-17; Törmä, 2015). Tämä huomioiden on selvää, että virtuaalisuudessa katoaa paljon jumalanpalveluksen ruumiillisesta ulottuvuudesta. Kirkkotilassa olemisen ruumiillis-uskonnollinen ulottuvuus merkitsee konkreettista yhdessä ja samassa tilassa olemista muiden tilaisuuteen osallistuvien kanssa. On merkitsevää, että jumalanpalvelus koetaan yhdessä. Jumalanpalvelus on näin interaffektiivinen ja interkorporeaalinen tilanne. Tämä ei tarkoita, että kaikki osallistujat kokisivat ja jakaisivat samat tunteet, vaan tunteet syntyvät samassa tilassa olevilla väistämättä ruumiillisen vuorovaikutuksen kautta. Intersubjektiivisesti ja enaktiivisesti muodostuvalla subjektiviteetillä voi selittää, kuinka yhteen kokoontuvalla seurakunnalla on merkitystä myös yhteisen uskon muodostumisen ja ylläpitämisen kannalta: seurakuntaa yhdistävä yhteinen usko voi muodostua vain, jos pidetään yllä todellisuutta, jossa uskon edellyttämät käsitykset tulevat eri subjektien yhteisesti koettaviksi. Ei ole tietenkään ilmeistä, millaisten mekanismien kautta ybteinen usko syntyy eikä tässä ole mahdollista syventyä tähän aiheeseen, mutta voi kysyä, miten seurakuntaa yhdistävä usko voisi syntyä tai pysyä yllä ilman rituaalia, johon seurakunta ruumiillisesti kokoontuu.

Kaikki jumalanpalveluksen keskeisistä elementeistä eivät kuitenkaan katoa virtuaalisesti välitettyinä. Jos laitteet toimivat hyvin, tilaisuuden toimittajien puhe kuuluu selvästi eivätkä tekniikan rajoitukset häiritse puhetta. Myöskään kirkkosalissa fyysisesti olemisen ulottuvuus ei tyystin katoa, vaan siitäkin välittyy jotain myös kuvan välityksellä. Monet jumalanpalveluksen rituaaliset toiminnot ovat luonteeltaan ruumiillisia, mutta jumalanpalvelukseen virtuaalisesti osallistuvat voivat kehitellä itselleen omaan kotiin sijoittuvia ruumiillisia tapoja, kuten tietylle tuolille ja paikalle asettuminen, ristin tai muun symbolisen esineen esiin ottaminen ja virsikirjan käteen ottaminen. Näin kotiin voi muodostua jumalanpalveluksen ajaksi kirkkotilalle ominainen pyhän paikan tuntu. Virtuaalista lähetystä seuraavasta voi muodostua siihen osallistuva, jos tämän huomioidaan tervehdyksin ja puhutteluin läpi jumalanpalveluksen. Virtuaalisesti jumalanpalvelukseen osallistuva 
voi tunnustaa syntinsä, kuulla synnintunnustuksen, laulaa virsiä, osallistua yhteiseen rukoukseen ja kuulla saarnaa, jolla pyritään puhuttelemaan häntä. Lisäksi virtuaalisuus mahdollistaa osallistumisen fyysisesti kaukana oleviin tilaisuuksiin, mikä voi edistää ekumeenisuutta ja ideaa kirkosta maailmanlaajana yhteisönä.

Jatkossa seurakunnille tulee harkittavaksi, jatketaanko tilaisuuksien välittämistä virtuaalisesti seurattavaksi (Salminen, 2021). Uudesta asiasta tässä ei ole kyse, vaan tilaisuuksia on radioitu ja televisioitu jo pitkään ja joissakin seurakunnissa jumalanpalvelusten lähettäminen paikallisradiossa on vakituinen tapa. Jumalanpalveluksen yhtenä perustavana elementtinä on konkreettisesti yhteen kokoontuminen. On olennainen kysymys, minkälainen rooli jumalanpalvelusta etäältä seuraaville annetaan: tervehditäänkö heitä osana jumalanpalvelukseen osallistuvia vai välitetäänkö tilaisuus ainoastaan heille seurattavaksi. Virtuaalisen etäyhteyden varassa jumalanpalvelusta seuraavasta voi muodostua siihen osallistuja. Tällöin osallistujien välinen sosiaalinen yhteys jää kokonaan puuttumaan ja jumalanpalvelukseen osallistuminen tapahtuu ikään kuin erikseen jokaisen osallistujan kohdalla.

Virtuaalisen tavoitteellisen yhteistoiminnan ja jumalanpalveluksen tarkasteleminen virtuaalisena toimintana paljastaa kiinnostavalla tavalla, millä tavalla ne eroavat toisistaan. Keskeinen ero koskee sosiaalisuutta ja vuorovaikutusta. Tavoitteellinen yhteistoiminta voi olla melko yksisuuntaista viestintää (esim. luento). Vuorovaikutuksen merkitys syvenee sellaisessa tavoitteellisessa toiminnassa, joka perustuu yhteiseen keskusteluun ja jossa kaikkien on sitouduttava yhteisen tavoitteen toteuttamiseen. Jumalanpalvelus ei kuitenkaan ole kahdensuuntaista vuorovaikutusta huolimatta siitä, että se on läsnäoloon perustuvaa ruumiillista toimintaa. Kuvaa ja ääntä välittävä virtuaalinen jumalanpalvelus voi ainakin osin mahdollistaa ruumiillisen osallisuuden jumalanpalvelukseen. Ruumiillinen osallisuus yhteydessä muihin jumalapalvelukseen osallistuvien kanssa ei kuitenkaan onnistu virtuaalisesti, vaan edellyttää fyysistä läsnäoloa. Jumalanpalveluksessa ruumiillisen osallisuuden kautta tapahtuvalla yhteydellä on lähtökohtaisesti emotionaalinen ulottuvuus. On ainakin potentiaalisesti emotionaalinen ja muihin jumalanpalvelukseen osallistuviin kohdistuva emotionaalinen kokemus, että kuuluu osaksi samaa, yhteiseen rituaaliin osallistuvaa, yhteisen uskon jakavaa seurakuntaa. 


\section{Johtopäätökset}

Tutkin virtuaalisen palvelun avulla tehtävää yhteistyötä sen valossa, että ihminen on ruumiillinen olento. Ensimmäinen virtuaalista yhteistyötä koskeva huomio on, että sekin on luonteeltaan ruumiillista toimintaa: viestintä tapahtuu edelleen kehollisten toimintojen ja aistien avulla. Kehollinen viestintä on kuitenkin virtuaalisissa palveluissa rajoittunutta. Emotionaaliset tunnesiteet muiden kanssa uhkaavat jäädä virtuaalisessa toiminnassa syntymättä ja ne näivettyvät. Siksi pitkäaikaisella, pelkästään virtuaalisten palveluiden varassa toimimisella voi olla negatiivisia seurauksia niin opinnoissa kuin työpaikoilla, joissa sosiaalisella toiminnalla ja niiden kautta rakentuvilla tunnesiteillä on olennainen merkitys.

Tavoitteellisen yhteistoiminnan lisäksi tutkin virtuaalista uskonnollista toimintaa. Keskityin jumalanpalvelukseen Suomen evankelis-luterilaisessa kirkossa. Jumalanpalvelukseen osallistuminen on nimenomaisesti ruumiillista toimintaa, jossa korostuu kirkossa olemisen, muiden läsnäolon ja vuorovaikutuksen merkitys. Uskonnollisuus ylipäätään on luonteeltaan ruumiillista siinä mielessä, että se on elettyä eikä niinkään intellektuaalista opin ja opetuksen omaksumista ja ymmärtämistä. Jumalanpalveluksen virtuaalisuus tietysti väistämättä hukkaa paljon tilaisuuden ruumiillisesta ulottuvuudesta, mutta ei kaikkea. Jumalanpalveluksen tarkoituksesta ja merkityksestä toteutuu paljon myös virtuaalisesti välitettyyn tilaisuuteen osallistumisen kautta. Ruumiilliseen osallisuuteen perustuva yhteys toisten osallistujien kanssa jää kuitenkin lähes kokonaan uupumaan. On tietysti syytä edelleen kysyä ja tutkia, mitä kaikkea tämä merkitsee uskonnollisen ja hengellisen elämän kannalta, mutta ruumiinfenomenologian valossa aiheella on syvällekäyvä merkitys.

Merleau-Pontyn kommunikaatiota koskevaan käsitykseen nojautuen voi sanoa, että vuorovaikutusta rikkovat virtuaalisen alustan rajoitteet eivät ainoastaan haittaa viestin välittämistä, vaan ne ulottuvat kysymyksiin ihmisenä olemisen perusasioista. Merleau-Pontyn filosofiassa kielen ja eleiden kautta tapahtuva kommunikaatio on keskeinen osa subjektiviteetin ja koko inhimillisen todellisuuden perustaa. Intersubjektiivisuuden kautta toteutuva maailman jaettuisuus edellyttää toisten ihmisten ymmärtämistä ja näiden kokemukseen eläytymistä kommunikaatiossa (Merleau-Ponty, 2012:185-192). Tältä perustalta voi sanoa, että virtuaalisen kanssakäymisen kommunikaatiota ja vuorovaikutusta haittaavat rajoitteet ulottuvat ihmisyyttä syvimmin mää- 
rittäviin asioihin. Tämä ei liity ainoastaan jumalanpalvelukseen, vaan myös tavoitteelliseen yhteistoimintaan, jossa on tavoitteen saavuttamisen lisäksi merkitystä osapuolten emotionaalisilla siteillä ja niiden kautta toteutuvalla yhteisyyden kokemuksella. Ruumiinfenomenologisen tarkastelun avulla voidaan huomioida, että ruumiilliseen läsnäolon mahdollistamat, toisia ihmisiä koskettavat, emotionaaliset kokemukset ovat olennaisia niin jumalanpalveluksessa kuin tavoitteellisessa toiminnassa.

\section{Kirjallisuus}

Asatiani, A., Hämäläinen, J., Penttinen, E., Rossi, M. (2021). Constructing Continuity across the Organisational Culture Boundary in a Highly Virtual Work Environment. Information Systems Journal. https://doi.org/10.1111/isj.12293

Bristow, W. (2017). Enlightenment. - E. N. Zalta (toim.), The Stanford Encyclopedia of Philosophy (Fall 2017 Edition). https:// plato.stanford.edu/archives/fall2017/entries/enlightenment

Cataldi, S. L. (1993). Emotion, Depth, and Flesh: A Study of Sensitive Space: Reflections on Merleau-Ponty's Philosophy of Embodiment. State University of New York Press.

Durt, C. (2017). Consciousness, Culture, and Significance.-C.Durt,C.Tewes \& T. Fuchs (toim.), Embodiment, Enaction, and Culture. Cambridge, MA; London: The MIT Press, 65-86. https://doi.org/10.7551/mitpress/9780262035552.003.0004

Ellis, R. \& Goodyear, P. (2010). Students' Experiences of e-Learning in Higher Education: The Ecology of Sustainable Innovation. Routledge.

Fay, M. J. \& Kline, S. L. (2011). Coworker Relationships and Informal Communication in High-Intensity Telecommuting. Journal of Applied Communication Research, 39(2), 144-163. https://doi.org/10.1080/009098 82.2011.556136

Gallace, A. \& Spence, C. (2016). Social Touch. - H. Olausson, J. Wessberg, I. Morrison \& F. McGlone (toim.), Affective Touch and the Neurophysiology of CT Afferents. New
York: Springer, 227-238. https://doi. org/10.1007/978-1-4939-6418-5_14

Hassett, M. E., Harikkala-Laitinen, R., Nummela, N. \& Raitis J. (2018). Emotions and Virtual Teams in Cross-border Acquisitions. - L. Petitta, C. E. J. Härtel, N. M. Ashkanasy, W. Zerbe (toim.), Individual, Relational, and Contextual Dynamics of Emotions, vol. 14. Emerald Publishing Limited, 163-187. https://doi.org/10.1108/ S1746-979120180000014016

Heinämaa, S. (1996). Ele, tyyli ja sukupuoli. Merleau-Pontyn ja Beauvoirin ruumiinfenomenologia ja sen merkitys sukupuolikysymykselle. Helsinki: Gaudeamus.

Mollahosseini, A., Abdollahi, H., Sweeny, T. D., Cole R. \& Mahoor, M.H. (2018). Role of Embodiment and Presence in Human Perception of Robots' Facial Cues. International Journal of Human-Computer Studies, 116, 25-39. https://doi.org/10.1016/j. ijhcs.2018.04.005

Ignat, C.-L., Bjørn P. \& Dewan P. (2018). Special Issue: ECSCW 2018: The 16th European Conference on Computer-Supported Cooperative Work, The International Venue on Practice-centred Computing and the Design of Cooperation Technologies. Computer Supported Cooperative Work (Vol. 27, Issues 3-6, s. 291-1020). Springer Verlag. https:// doi.org/10.1007/s10606-018-9334-0

Knapp, M. L., Hall, J. A, Horgan, T. G. (2014). Nonverbal Communication in Human Interaction. Eighth Edition. Boston: Wadsworth.

Kolodny, N. \& John B. (2020). Instrumental 
Rationality. - Edward N. Zalta (toim.), The Stanford Encyclopedia of Philosophy (Spring 2020 Edition). https://plato.stanford.edu/archives/spr2020/entries/rationality-instrumental/

Kuepers, W. (2010). 'Inter Place'-Phenomenology of Embodied Space and Place as Basis for a Relational Understanding of Leader- and Followship in Organisations. Environment Space Place. https:// doi.org/10.7761/ESP.2.1.81

Lehikoinen, E. (2021). Opettajat pandemian keskellä: Työjärjestelyjen ja yksilöllisten tekijoiden vaikutus peruskouluopettajien kokemuksiin työhyvinvoinnista keväällä 2020. Helsinki: Helsingin yliopisto.

Lindström, A. (2021). Työhyvinvoinnin kuormitus- ja voimavaratekijöitä tietotyöntekijöiden etätyössä: Kokemuksia koronapandemian ajalta. Helsinki: Helsingin yliopisto.

Martikainen, S., Wikström, V., Falcon, M., \& Saarikivi, K. (2019). Collaboration Faceto-Face and in Virtual Reality - Empathy, Social Closeness, and Task Load. Conference Companion Publication of the 2019 on Computer Supported Cooperative Work and Social Computing, 299-303. https://doi. org/10.1145/3311957.3359468

McGuire, M. B. (2008). Lived Religion. Faith and Practice in Everyday Life. New York: Oxford University Press. https://doi. org/10.1093/acprof:oso/9780195172621. 001.0001

McNeill, D. (2005). Gesture and Thought. Chicago; London: The University of Chicago Press. https://doi.org/10.7208/chicago/9780226514642.001.0001

Merleau-Ponty, M. (2012). Phenomenology of Perception. Kääntänyt D. A. Landes. London; New York: Routledge. https://doi. org/10.4324/9780203720714

Metzinger, T. K. (2018). Why Is Virtual Reality Interesting for Philosophers? Frontiers in Robotics and AI, 5, 101-101. https://doi. org/10.3389/frobt.2018.00101

Pihlström, S. (2010). Fenomenologia ja pragmatismi. - T. Miettinen, S. Pulkkinen \& J. Taipale (toim.), Fenomenologian ydinkysymyksiä. Helsinki: Gaudeamus, 236-248.
Rendle-Short, J. (2006). The Academic Presentation: Situated Talk in Action. Hampshire: Ashgate Publishing Limited.

Salminen, V.-M. (2021). Seurakuntatyö pitkittyneessä poikkeustilassa. $R a-$ portti kirkon työntekijoiden ja luottamushenkilöiden koronakyselystä 2021. Kirkon tutkimuskeskus. https://evl.fi/ documents/1327140/50112189/Raportti+KTK+koronakyselyst\%C3\%A4+2021_ Saavutettava2.pdf/8bbd3528-7bb1-1ccbacac-12604e78abf2?t=1615545968213 (luettu 30.10.2021).

Salomäki, H. (2020). Seurakunnat ja koronakriisi. Kirkon tutkimuskeskus. https:// evl.fi/documents/1327140/50112189/ Seurakunnat+ja+koronakriisi+2020. pdf/69a939cd-e0c2-4803-9422-af$53 \mathrm{ca} 80 \mathrm{c} 4 \mathrm{db} ? \mathrm{t}=1590475691191-$ luettu 30.10.2021.

Scarantino, A. \& de Sousa, R. (2018). Emotion. - E. N. Zalta (toim.), The Stanford Encyclopedia of Philosophy (Winter 2018 Edition). https://plato.stanford.edu/archives/win2018/entries/emotion - luettu 2.3.2021. https://doi.org/10.1177/1754 073918772090

Schott, R. M., Heinämaa, S. \& Songe-Moller, V. (2010). Birth, Death, and Femininity: Philosophies of Embodiment. Indiana University Press.

Stephenson, B. (2018). Ritual as Action, Performance, and Practice. - R. Uro, J. J. Day, R. Roitto \& R. E. DeMaris (toim.), The Oxford Handbook of Early Christian Ritual. Oxford: Oxford University Press, 38-54. https://doi.org/10.1093/oxford$\mathrm{hb} / 9780198747871.013 .3$

Sundar, S. S. (2015). The Handbook of the Psychology of Communication Technology. Wiley Blackwell. https://doi. org/10.1002/9781118426456

Taipale, J. (2010). Intersubjektiivisuus ja normaalius. - T. Miettinen, S. Pulkkinen \& J. Taipale (toim.), Fenomenologian ydinkysymyksiä. Helsinki: Gaudeamus, 118-133.

Taylor, C. (2007). A Secular Age. Oxford: Oxford University Press. https://doi. org/10.2307/j.ctvxrpz54 
TESIS. Towards an Embodied Science of InterSubjectivity. https://tesisnetwork.wordpress.com - luettu 31.10.2021.

Tewes, C., Durt C. \& Fuchs T. (2017). Introduction: The Interplay of Embodiment, Enaction and Culture. - C. Durt, C. Tewes $\&$ T. Fuchs (toim.), Embodiment, Enaction, and Culture. Cambridge, MA; London:The MIT Press, 1-22. https://doi.org/10.7551/ mitpress/9780262035552.003.0001

Törmä, T. (2015). Oma ruumis ja kerronnan kaari. Merkityksen muodostuminen Maurice Merleau-Pontyn ruumiifenomenologisen ja Paul Ricoeurin narratiivisen imaginaatiokäsityksen mukaan. Suomalaisen Teologisen Kirjallisuusseuran julkaisuja 282. Helsinki: STKS.
Varela, F.J.,Thompson, E., \& Rosch, E. (1991). The embodied mind: Cognitive science and buman experience. The MIT Press. https:// doi.org/10.7551/mitpress/6730.001.0001

Vásquez, M. A. (2011). More than Belief. A Materialist Theory of Religion. New York: Oxford University Press.

Wiklund, M., Honko M., Kanto L. \& Råman J. (2021). Pitkittyneen etäajan vaikutuksista kielentutkimukseen ja alan opetukseen. Helsinki: Helsingin yliopisto, kielten osasto.

Wikström, Martikainen, S., Falcon, M., Ruistola, J., \& Saarikivi, K. (2020). Collaborative block design task for assessing pair performance in virtual reality and reality. Heliyon, 6(9), e04823-e04823. https://doi. org/10.1016/j.heliyon.2020.e4823 